\title{
The forming mechanisms of Oligocene combination/stratigraphic traps and their reservoir quality in southeast Cuu Long Basin offshore of Vietnam
}

\author{
Nguyen Dinh Chuc ${ }^{1},{ }^{*}$, Tran Van Xuan ${ }^{1}$, Nguyen Xuan Kha ${ }^{1}$, Tran Nhu Huy ${ }^{2}$, Mai Thanh Tan ${ }^{3}$
}

${ }^{1}$ University of Technology VNU-HCM

${ }^{2}$ PetroVietnam Exploration Production Company

${ }^{3}$ University of Mining \& Geology, Hanoi

\section{Correspondence}

Nguyen Dinh Chuc, University of Technology VNU-HCM

Email: ndchuc1977@gmail.com

\section{History}

- Received: 2018-11-30

- Accepted: 2019-03-19

- Published: 2019-03-31

DOI : $10.32508 /$ stdj.v22i1.1216

\section{Check for updates}

\section{Copyright}

(c) VNU-HCM Press. This is an openaccess article distributed under the terms of the Creative Commons Attribution 4.0 International license.

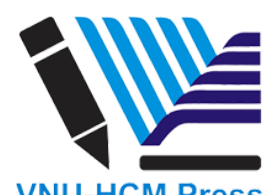

\begin{abstract}
To date, most of the oil and gas production in Cuu Long Basin (CLB) is contributed from structural traps, making them more and more depleted after years of exploitation. Exploration activities in CLB, therefore, are shifting towards other traps, including stratigraphic and/or combination ones. The results of exploration and appraisal activities in recent years have increasingly discovered more hydrocarbons in the Oligocene section; some of them were discovered in combination/stratigraphic traps. Many studies on Oligocene targets in Southeast CLB have been carried out but only a few mention nonstructural traps. This leads to uncertainty about the forming mechanisms and distribution, as well as unevaluated hydrocarbon potential of these traps. An integrated approach- utilizing methods of seismic sequence stratigraphy, seismic attribute interpretation, and petrophysical/ petrographical analysis- was applied in this research to identify the forming mechanisms of Oligocene combination/ stratigraphic traps in southeast area of CLB and to evaluate their reservoir quality. The research results show that the key forming factor for stratigraphic traps of sand body is lithology change and the one for pinch-out stratigraphic traps is tapering off of sand layers landward or toward the horsts. The reservoir quality of these traps ranges from moderate to good. By integratedly applying the methods, the forming mechanisms and reservoir quality of Oligocene stratigraphic traps could be delineated. In order to optimize the next-stage exploration strategy in CLB, detailed studies on petroleum system, especially top and bottom seals, and the hydrocarbon potential of these stratigraphic traps, need to be carried out.
\end{abstract}

Key words: Hydrocarbon potential, stratigraphic trap, forming mechanism, reservoir quality

\section{INTRODUCTION}

Cuu Long Basin (CLB) is a matured basin with high density of exploration and production activities. So far, it is the most important sedimentary basin contributing greatly to Vietnams annual petroleum production. The major targets for exploration and production in CLB have been pre-Cenozoic fractured basement highs and Cenozoic structural traps of tectonically formed anticlines. In recent years, petroleum production from conventional structural traps in CLB has declined gradually, and exploration for new structural targets is facing technical difficulties, limited potential and commercial issues. Thus, petroleum exploration needs to focus on more potential but more complicated targets, such as stratigraphic/combination traps.

Several research studies were conducted in CLB, to search for non-structural traps, showing that there existed pinch-out traps in Oligocene deposits that were distributed along the Northwestern monocline of Con Son Swell ${ }^{1-4}$. However, these traps were not paid sufficient attention in petroleum exploration due to low petroleum potential evaluated. As a result, these non-structural traps are ordinarily considered as additional targets in exploration in CLB.

Recently, exploration activities in the southeastern margin of CLB have identified several stratigraphic traps formed by appropriate changes in rock facies. Their existence has been confirmed through several wells. These are new exploration targets in southeastern CLB. These findings have opened up a new direction for petroleum exploration of potential stratigraphic/combination traps in southeastern $\mathrm{CLB}^{5}$.

Nevertheless, prospecting these non-structural traps is a difficult task due to the complex distribution and large range of exploration risks. Therefore, additional studies and assessments of recently discovered nonstructural traps need to be carried out in order to support future exploration and appraisal programs in CLB. This paper focuses on the identification of several trap types ascertained in the Oligocene section and their distribution, as well as the main risks in exploration using various methods of seismic stratigraphy and seismic attribute analysis in conjunction with offshore of Vietnam. Sci. Tech. Dev. J.; 22(1):185-195. 
well log interpretation and other geological data. Further discussions on the reservoir qualities of the combination/stratigraphic traps are also mentioned, with some examples in the southeastern margin of CLB, in order to support for exploration of non-traditional targets and appraisal of the discovered structural traps in this area as well.

\section{DATA AND METHODOLOGY}

\section{Geological Settings \\ Basin evolution}

Cuu Long Basin is a Cenozoic rift basin located in the southeastern shelf of Vietnam. Geological evolution of CLB is divided into three periods: pre-rift, syn-rift and post-rift ${ }^{1,6}$ :

First period (pre-rift)

From Jurassic to the end of Cretaceous; formation of granitoid basement. This period included two consecutive tectonic processes: subduction (that formed diorite, granodiorite and biotite-rich granite) and seafloor spreading (that led to the formation of mountains with feldspar-rich granite). From Late Cretaceous to Early Eocene of Paleogene, CLB was a part of the Indochina Uplift ${ }^{1}$.

Second period (syn-rift)

From Late Eocene to Early Miocene; alternating between phases of extension that formed NE-SW, E-W and N-S fault systems and phases of compression that formed folds, normal faults, thrust faults and strikeslip faults ${ }^{6}$.

\section{Third period}

Passive continental margin from Middle Miocene to the Quaternary ${ }^{1}$.

\section{Stratigraphy}

The stratigraphic column of the southeastern margin as well as the whole Cuu Long Basin can be summarized as follows (Figure 1) ${ }^{1}$ :

\section{Pre-Tertiary Basement Complex}

This plutonic intrusive complex is composed of various Pre-Tertiary rocks, with the majority being granite, granitoid and granodiorite. In addition, it was occasional sheared, in part, by extrusive Rhyolite. These rocks are characterized by their heterogeneous minerals, resulting from the formation conditions. In analogue with adjacent areas, such as Bach Ho and Rong basement complexes, of which their absolute age had been dated by radioactive isotope method, the age of this complex could be classified as Jurassic and Cretaceous belonging to the Dalat-Cambodia zone. The main mineral composition consists of predominantly Quart and Plagioclase Feldspar, a minor amount of Mica (almost Biotite) and Kaolinite (altered from Feldspar).

Lower Tra Tan-Tra Cu Formation - Oligocene E

This continental sediment consists of shale, siltstone and sandstone which were deposited unconformably on the Pre-Tertiary basement. It is distributed widely across the southeastern sub-basin and is divided into two sub-units: Oligocene E Lower (in the lower part) and Oligocene E Upper (in the upper part). The lower one is dominated by medium- to coarse-grained sandstones composed of mostly granitic fragments and feldspars, and interbedded with hard organic-rich black shale layers. The other one is composed predominantly of fine- to medium-grained sandstones interbedded with gray shale layers. In addition, magma intrusions, such as dykes, are found occasionally and composed predominantly of andesite/basalt.

\section{Upper Tra Tan Formation - Oligocene D}

This column consists predominantly of organic-rich brown shale deposited in lacustrine environment, occasionally interbedded with local layers of coal or sandstone. However, toward the eastern boundary of the sub-basin (close to Con Son Swell), thick layers of sandstone are deposited on top of the Oligocene D shale.

Upper Tra Tan Formation - Oligocene C

This section consists of mixtures of fine-grained sandstones and lacustrine brown shale.

Bach Ho Formation - Miocene BI

This stratigraphic sequence is divided into two subunits- Miocene BI.1 (lower part) and Miocene BI.2 (upper part). Miocene BI.1 is composed mainly of sandstone-dominant fluvial-deltaic deposits with small intercalations of shale deposited in floodplain or some brackish environments, while Miocene BI.2 is composed mainly of sandstone interbedded with shale/claystone, occasional shallow marine siltstone and limestone. The top section of Miocene BI is Bach Ho shale, a thick and continuous shale layer, acting as a regional seal for the whole CLB.

\section{Petroleum systems}

Two matured source rocks in CLB are shales in Lower Oligocene + Eocene (?) and in Upper Oligocene ${ }^{7}$. 


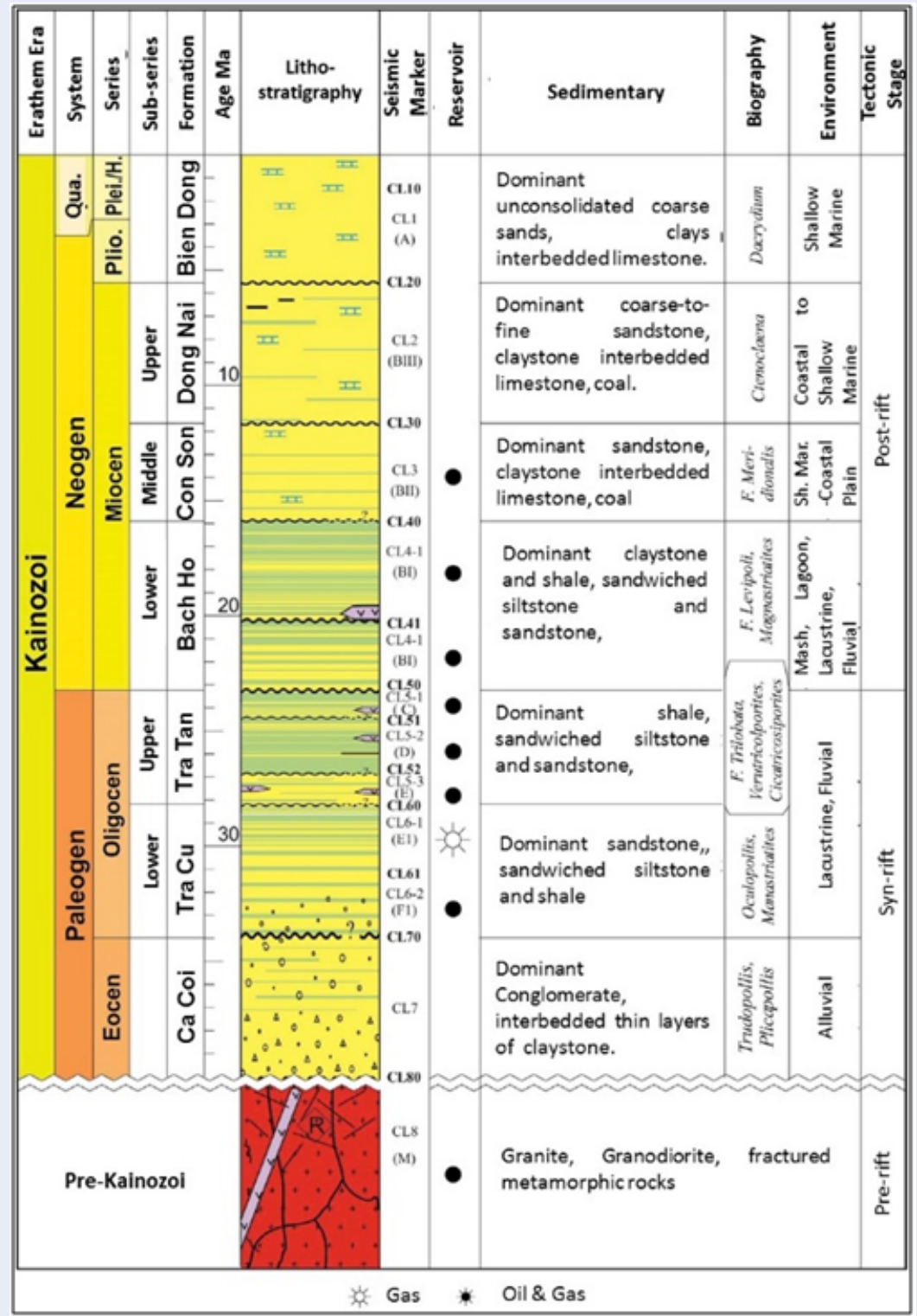

Figure 1: Generalized litho-stratigraphic column of Cuu Long Basin ${ }^{1}$. The target interval in this research study is Upper Oligocene sediments (Tra Tan Formation), having main lithologies of shale, sandy silstone and sandstone that were deposited in fluvial to lacustrine environments.

The reservoirs in CLB are fractured granitoid basements and Cainozoic sandstones aged from early Oligocene to early Miocene. Besides, there could be middle Miocene sandstone reservoirs in the eastern area of CLB. The seals in CLB are confirmed to include one regional and four local shale layers. The regional one is Rotalia shale in Bach Ho formation. The other four are shales in Con Son, Bach Ho, Tra Tan (C and $\mathrm{D}$ sequences), and in Tra $\mathrm{Cu}$ formation. In CLB, the traps are defined to be structural, stratigraphic and combination ones. They were mostly formed during syn-rift and early post-rift periods. Migration timing of Lower Oligocene + Eocene (?) source rock started in early Miocene and reached max in middle Miocene. The migration timing of Upper Oligocene source rock started in late Miocene. These timings occurred later than those of trap formation, thus making it favorable for hydrocarbons to be trapped ${ }^{1}$.

\section{Database}

This research was accomplished utilizing several 2D/3D seismic surveys and petrophysical data from 
some wells in CLB. Data of regional geology and results of some unpublished reports were also included as database for this research.

\section{Methodology}

In this article, we utilize an integrated approach of different exploration methods to assess various Oligocene traps in CLB. These methods are seismic sequence stratigraphy, seismic attribute analysis, petrophysical interpretation, petrographical analysis, and biostratigraphy. Seismic sequence stratigraphy is based on analysis of patterns of seismic reflectors and analysis of sequences and system tracts ${ }^{8,9}$. Seismic attribute analysis is based on the application of different attributes to enable the interpretation of depositional environment as well as the identification of internal patterns in stratigraphic units ${ }^{10,11}$. Petrophysical analysis allows detailed interpretation of geologic sections and provides information on lithology, facies and reservoir characteristics, as well as sequence stratigraphy ${ }^{12}$. Other supporting methods, including petrographic analysis and paleo-biostratigraphy, play an important role in the interpretation of depositional environments.

\section{RESULTS}

A series of hydrocarbon fields and discoveries in the Oligocene section have been identified by exploration and appraisal drilling in CLB. They appear to trend in the main axis of CLB (Figure 2). Almost all of these fields and discoveries are structural traps formed as anticlines on top of basement highs. However, integrated studies and oil and gas exploration activities in recent years have shown that oil and gas accumulations exist in both structural and stratigraphic traps, such as facies change traps, pinch-outs or truncations. These traps have different trapping mechanisms, risks and different distributions in CLB. This section reviews several trap types and forming mechanisms as well as their main risks in CLB, focusing on the stratigraphic/combination traps.

\section{Structural traps}

These trap types developed mainly over the pre-rift basement highs (Figure 3a). The trap forming mechanism is determined to be the consequence of postdepositional tectonic activities forming anticlines or draping over the existent topography highs. Tectonic inversion can be a favorable condition for structural traps to form. These traps are sealed at the top by a number of overlying shale layers (Figure 3a). Lateral seals of these structural traps are 4-way closure types or fault-dependent trap types in which a tectonic seal is created on the downdip of the structures (Figure 3b). The structural traps distribute widely in CLB but mostly in the center of the basin. The main risks in exploring these trap types are mostly related to sealing, especially fault seal. In some places, source rock and migration complexities could add additional risk into prospecting these trap types due to long distances from the source areas in CLB.

\section{Stratigraphic traps}

Several types of stratigraphic traps have been identified within upper Oligocene sediments in the southeastern area of CLB. They are facies change (sand body), and pinch-out and truncation (unconformityrelated) traps. Some of these have been confirmed by drilling, thus making them important in oil and gas exploration. The distribution of these traps is evidenced in the eastern and southeastern areas of CLB (Figure 2). They were formed by lithology changes, tapering off of sand layers or truncation and burial of underlying strata. These traps are sealed at the top and base by overlying and underlying shale layers, respectively. Their lateral seals are interpreted to be lithology changes from fine-grained to coarse-grained sediments. Storage capability of these traps is from moderate to good with moderate to good top seal capacity and poor to moderate bottom seal capacity. These stratigraphic traps have more risks in exploration than the structural ones, most of which are sealing capacity of both top and lateral bottom ones.

\section{DISCUSSION}

\section{The forming mechanisms of Upper Oligocene stratigraphic traps \\ Facies change traps}

This kind of stratigraphic trap was identified in some places in the southeastern areas of CLB, such as KTN (in Oligocene $\mathrm{C}$ sequence), SoN (in Oligocene D sequence) and Ca Tam (Oligocene D) ${ }^{5,13}$. The trap is interpreted to be sand bodies that could be sand fans, as in the case of the KTN, or channel sands, as in the case of SoN (Figure 4). Lithology changes from coarse-grained to contemporaneously deposited finegrained sediments are the key factor to form these stratigraphic traps.

The overlying fine-grained sediments that were deposited during highstand stage of water level act as a top seal for these traps. Lateral and bottom seals for the traps are fine-grained sediments (Figure 5).

Well data analysis show that the overlying strata of the trap consist mainly of shale/clay, interbedded with minor sandstones with thickness of more 


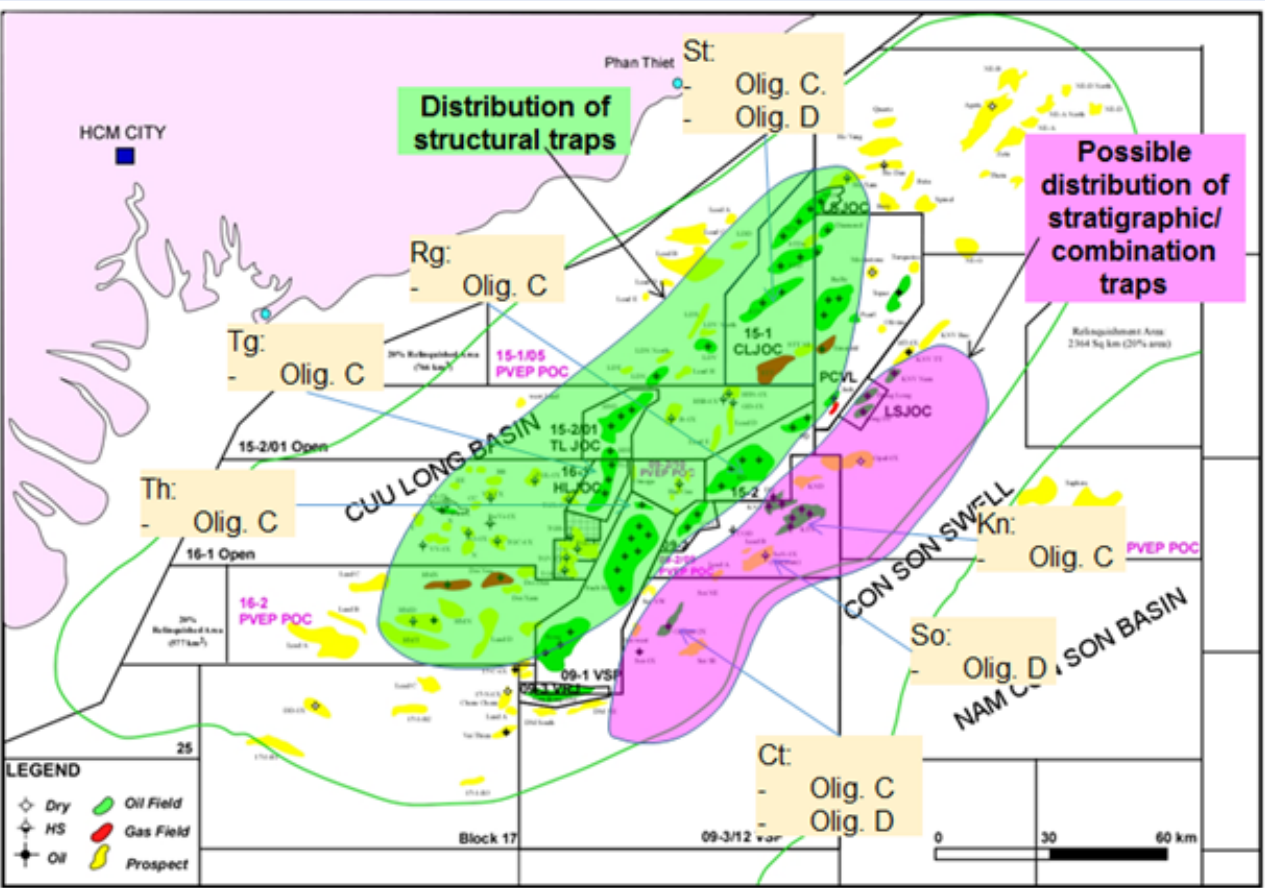

Figure 2: Cuu Long Basin (CLB) map showing the locations of hydrocarbon discoveries/prospects and possible distribution of trap types in Upper Oligocene sediments. The structural traps distribute mostly in the center of CLB. The stratigraphic/combination traps are evidenced to develop in the eastern and southeastern area of the basin.
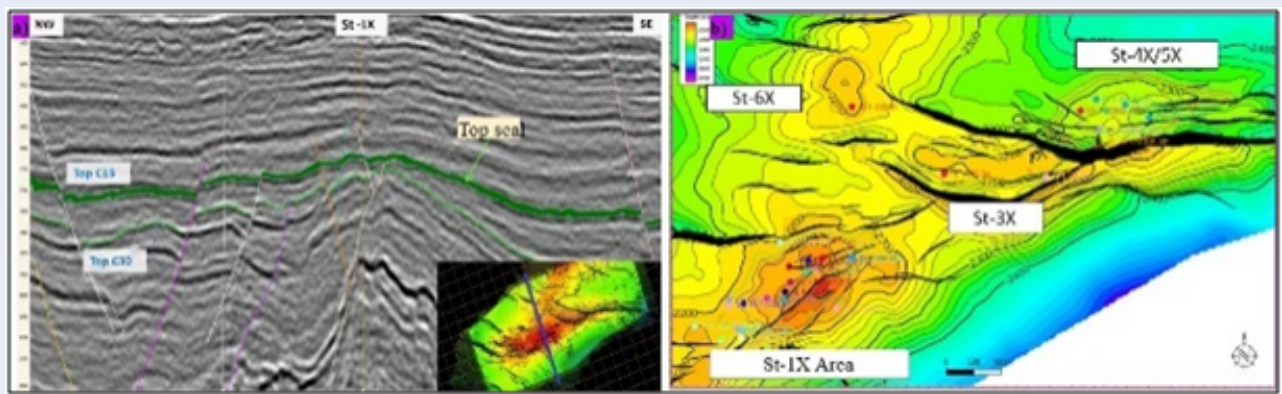

Figure 3: a) Seismic section though an anticline formed by post-depositional tectonics; b) Depth map of a structural trap showing four-way closure.

than $17 \mathrm{~m}$ deposited in flood plain environment (Figure 6) ${ }^{5}$. The underlying strata consist of very thick brown shale layers deposited in lacustrine environment. These Oligocene $\mathrm{D}$ shales are believed to be a very good seal in CLB. These analyses show that both top and bottom seals for this stratigraphic trap are interpreted to be the best type.

Seismic attribute analysis is applied to predict the distribution of seals for this trap. It could be inferred from seismic attribute map (Figure 7) that there is a high possibility of shale distribution of both overlying and underlying strata over the trap area. This reveals that the trap has good sealing capacity at both top and bottom positions.

Based on evidence derived from seismic data analysis (Figure 8a and Figure 8b), this stratigraphic trap is predicted to be distributed along the eastern margin of CLB where there is a steep slope (Figure $8 \mathrm{c}$ ). To discover this type of trap, explorationists need to thoroughly predict a number of significant factors, including depositional environmental and lithological changes, as well as evaluating the petroleum system 


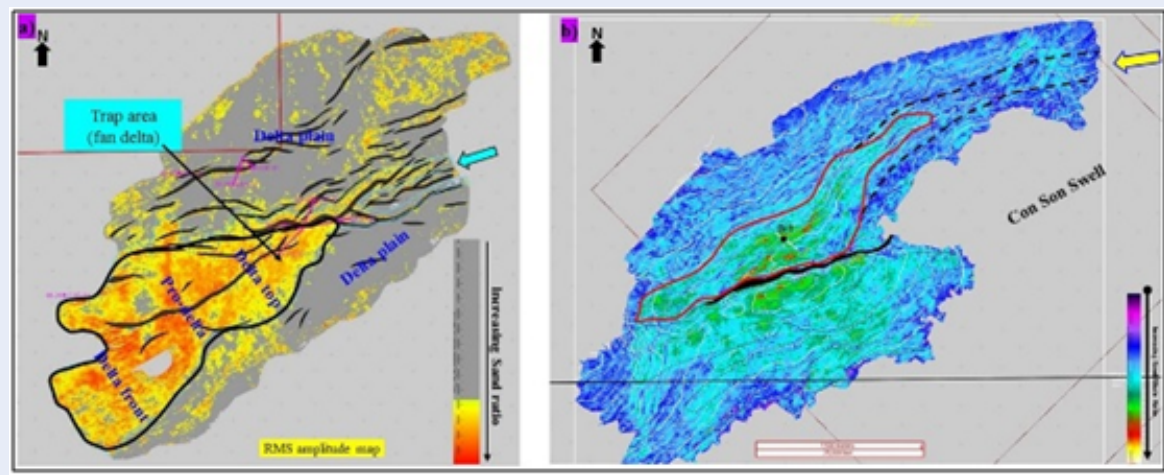

Figure 4: Interpretation of stratigraphic traps in block 09-2/09. a) Fan trap deposited in deltaic environments during lowstand stage of water level; b) Channel sands deposited during highstand stage of water level. The trapping mechanism is interpreted to be lithology changes from coarse-grained sediments to fine-grained sediments.

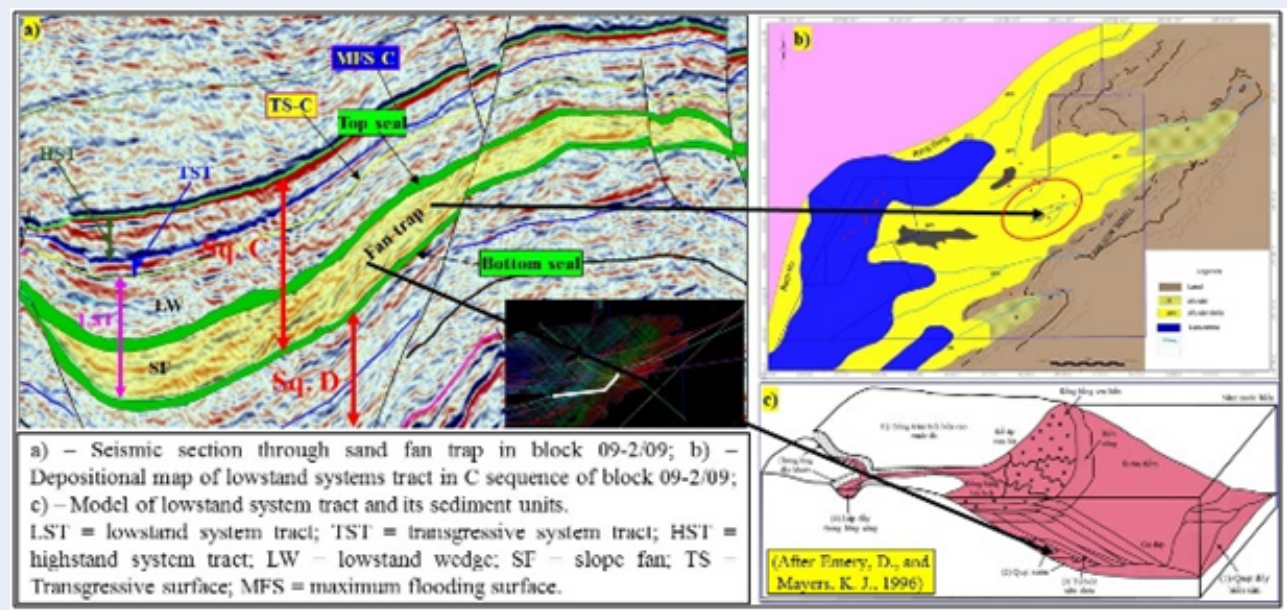

Figure 5: a) Seismic section through a stratigraphic fan trap that is interpreted to have formed during lowstand stage of water level in deltaic environment; b) Depositional environment map of LST in C sequence; c) Model of LST and its sediment units.

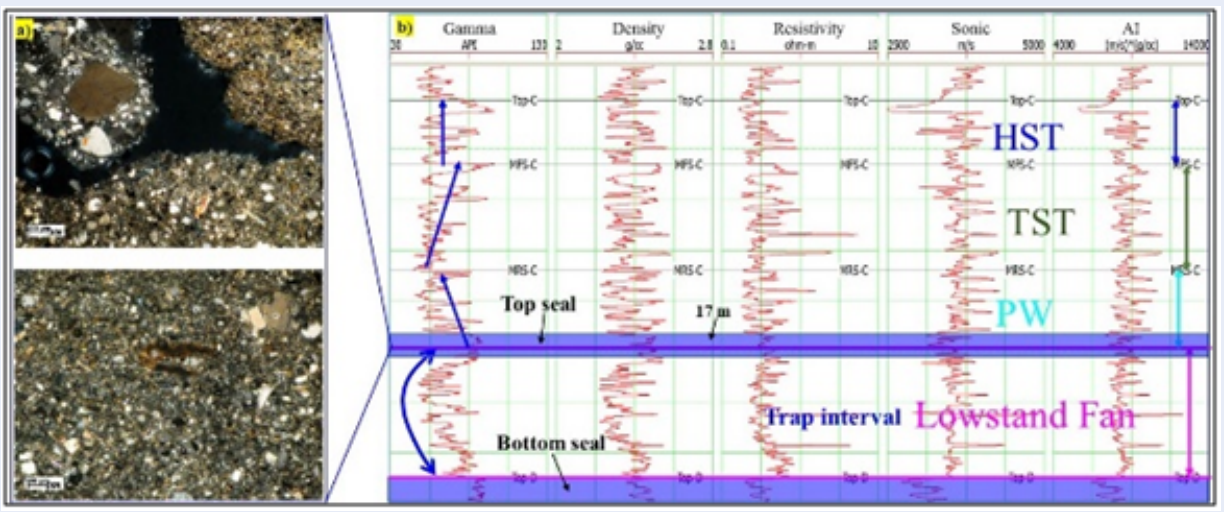

Figure 6: Well data analysis of stratigraphic fan trap in block 09-2/09: a) Petrographical analysis of overlying strata showing mostly shale/claystones interbedded with minor sandstones ${ }^{14}$; b) Petrophysical interpretation showing about $17 \mathrm{~m}$ top seal and thick Oligocene D shale acting as bottom seal. 


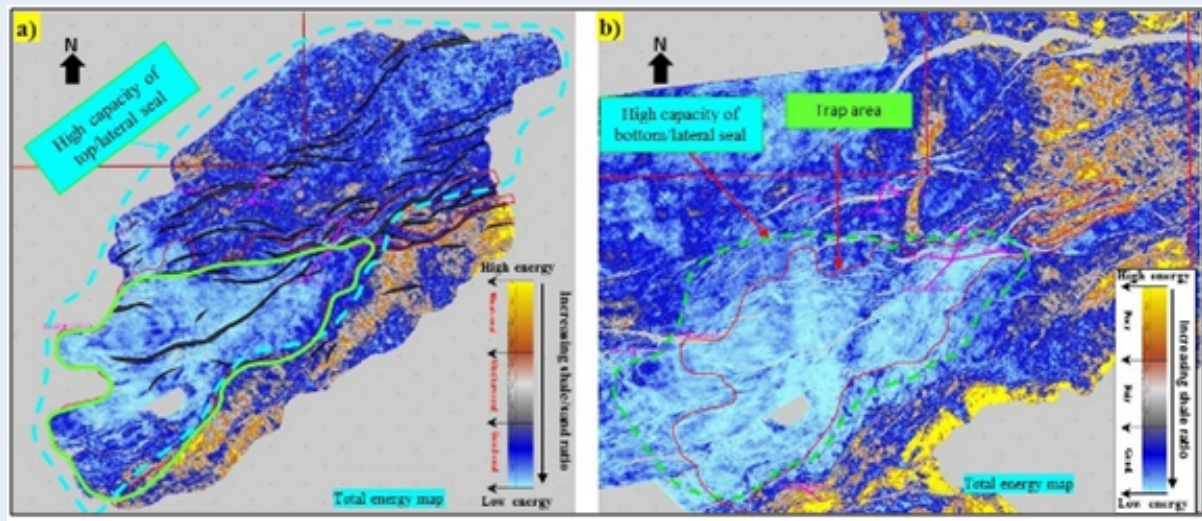

Figure 7: Sealing capacity prediction for top seal (a) and bottom/lateral seal (b) for the stratigraphic fan trap in block 09-2/09 using seismic attribute analysis. Both seismic attribute maps show that there is high possibility of shale distributions over the trap area represented by low total energy anomalies.
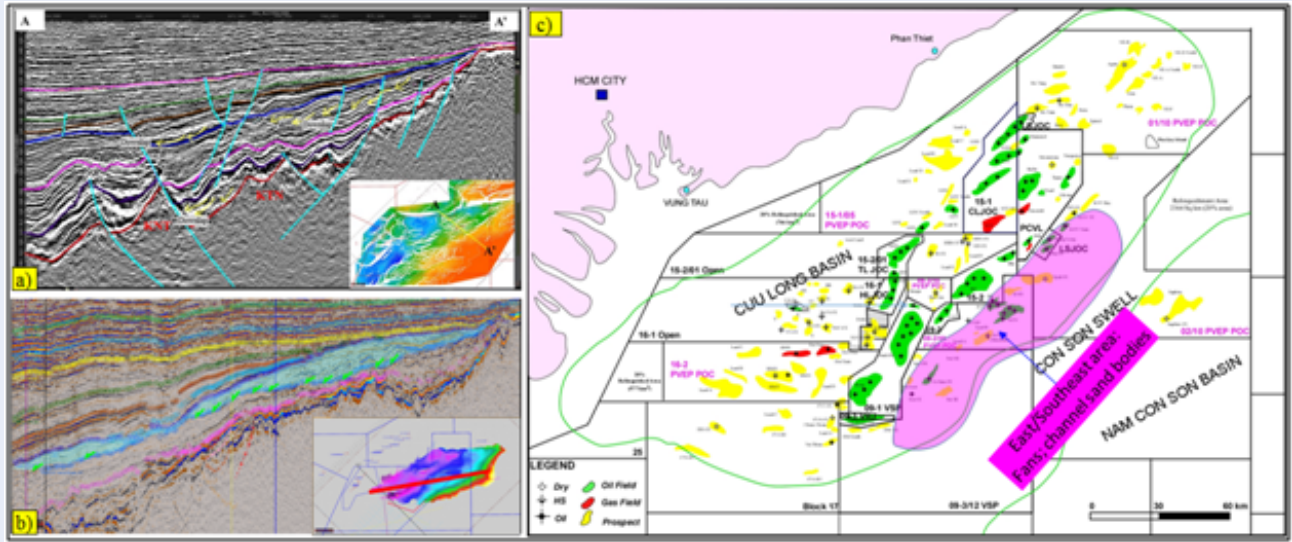

Figure 8: Possible distribution of stratigraphic traps in southeastern margin of CLB. a) NW-SE seismic section showing progradation of reflections toward the basin center; $b$ ) E-W section showing seismic characteristics that could be related to prograding deltaic depositions; $c$ ) Predicted distribution of fan-shaped traps in Oligocene section of CLB.

with great care for the lateral and bottom seals.

\section{Other stratigraphic traps}

Pinch-out traps

This kind of stratigraphic trap was identified in some places at the southeastern margin of CLB. They were formed due to the tapering off of sand layers landward or toward the horsts. These sand layers were overlain by finer-grained sediments deposited in during the high-stand stage of water level that acted as top seal for these traps. The bottom seal is determined to be the underlying shale layers or the ones in Oligocene D sequence. The lateral seal could be facies change into contemporaneously fine-grained sediments or tectonic sealing, such as fault sealing or structural closing
(Figure 9a). For the latter case, the trap becomes the combination trap. These traps often have better reservoir heterogeneity and clearer reservoir boundaries than facies-changed stratigraphic traps. Therefore, this trap type normally has good reservoir quality. This kind of stratigraphic traps is interpreted to distribute at the eastern margin of the basin as well as areas close to the basement highs (Figure 8c). It is, however, necessary to have a concrete prediction about lithology changes as well as to evaluate the petroleum system with great care on lateral and bottom seals, just the same as facies-changed stratigraphic traps. 


\section{Unconformity-related trap (truncation)}

Besides the above-mentioned stratigraphic trap types, it is possible to identify the unconformity-related stratigraphic trap in the study area. By applying seismic analysis, this kind of stratigraphic trap is interpreted to be truncation trap (below unconformity). Seismic data analysis shows that strong erosion of the highstand system tract (HST) of D sequence occurred in the eastern part of bock 09-2/09. These sandy sediments of HST in D sequence were then overlain by fine-grained sediments acting as a top seal (Figure 9b). The bottom/lateral seal for the trap is determined to be fine-grained sediments in the transgressive system tract of D sequence. Exploring these traps could be performed in the erosional areas of Oligocene strata adjacent to Con Son Swell. However, further detailed studies focusing on top and lateral seals, reservoir distribution and hydrocarbon potential should be carried out in order to reduce risks in the exploration activities.

\section{Reservoir quality of strati- graphic/combination traps:}

As mentioned earlier, several kinds of stratigraphic/combination traps have been identified in the Oligocene section in CLB, most of which are located in the southeastern areas of the basin. Some of them are confirmed by exploration drilling. This section shall focus on some evaluations of reservoir quality of the discovered stratigraphic/combination traps in the southeastern margin of CLB.

\section{Facies change traps}

This kind of stratigraphic trap was confirmed by drilling in several places, such as KTN (in C sequence) and SoN (in D sequence). In KTN wells, the reservoir interval has moderate to good oil shows while drilling ${ }^{5}$. Petrophysical interpretation shows that the reservoir interval is $20-30 \mathrm{~m}$ thick, with porosity ranging from 16 to $22 \%$ (Figure 10a) ${ }^{5}$. Results of petrographical analysis indicate that the lithology of reservoir interval consists of sandstones interbedded with shales and claystones. Sandstones are coarse very coarse grain, poor very poor sorted, sub-angular, and sub-rounded to rounded. The rock composition is composed of mostly granitic fragments, quartz and quartzite, showing that the sediment supply is from nearby basement highs (Con Son Swell). In addition, grain size is quite large $(0.5-5 \mathrm{~mm})$, showing that the reservoir was formed in shallow water environment with high energy (Figure 10b) ${ }^{14}$. These analyses of well data reveal that the reservoir has moderate to good quality.
Seismic attribute analysis integrated with well log interpretation shows that the stratigraphic trap has a fan-shaped distribution of more than $88 \mathrm{~km}^{2}$ (Figure 4a). The reservoir porosity of the trap is predicted by applying artificial neuron network using database of both seismic attributes and well log data. The results show that the predicted porosities of the traps reservoir are from $12 \%$ to $20 \%$, consistent with the calculated porosities derived from well log interpretation (Figure 11). This means that the porosity prediction for the traps reservoir using seismic data has high confidence.

\section{Other stratigraphic traps}

Other kinds of undrilled stratigraphic traps are also identified in the study area using seismic data analysis. They are pinch-out and truncation traps located in the southeastern margin of CLB. Although these traps have not been penetrated by drilling, their reservoir distribution and other characteristics are also predicted in order to support for further exploration of these traps in the future.

\section{Pinch-out traps}

The result of porosity prediction for the reservoir of this trap type shows that in the trap's area, the predicted porosities are from $9 \%$ to $16 \%$, with $14.5 \%$ on average (Figure 12a). This reveals that the reservoir of the trap has medium quality.

Unconformity-related stratigraphic trap (truncation): As the above-mentioned forming mechanisms, these traps are predicted to distribute in the erosional areas close to Con Son Swell. Stratigraphy in these areas is mostly sandy sediments deposited at the near-source areas. Therefore, the reservoir quality of these traps is predicted to be good. This is supported by porosity prediction for reservoir of the truncation trap in the study area (Figure 12b), ranging from $9 \%$ to $20 \%$, with $17 \%$ on average.

\section{CONCLUSION}

The presented study discussed the research methodology and practical issues associated with assessing different Oligocene trap types, trapping mechanisms, and associated risks in exploration in CLB. Based on the results, several statements can be concluded as following:

- Oil and gas in the Oligocene section were accumulated in both structural and stratigraphic traps with different forming mechanisms. The structural traps could develop widely in CLB. 


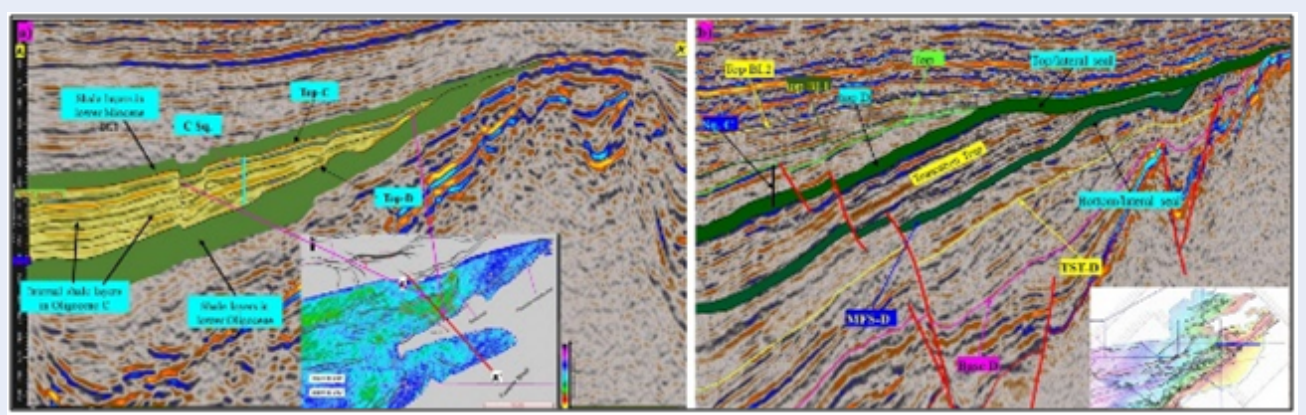

Figure 9: Interpreted seismic sections through the stratigraphic traps in the southeastern margin of CLB: a) Pinch-out trap formed by the tapering off of sand layers landward or toward the horsts; b) Truncation trap formed by tectonic uplifting and truncation of underlying strata and later draping of fine-grained sediments over the trap.

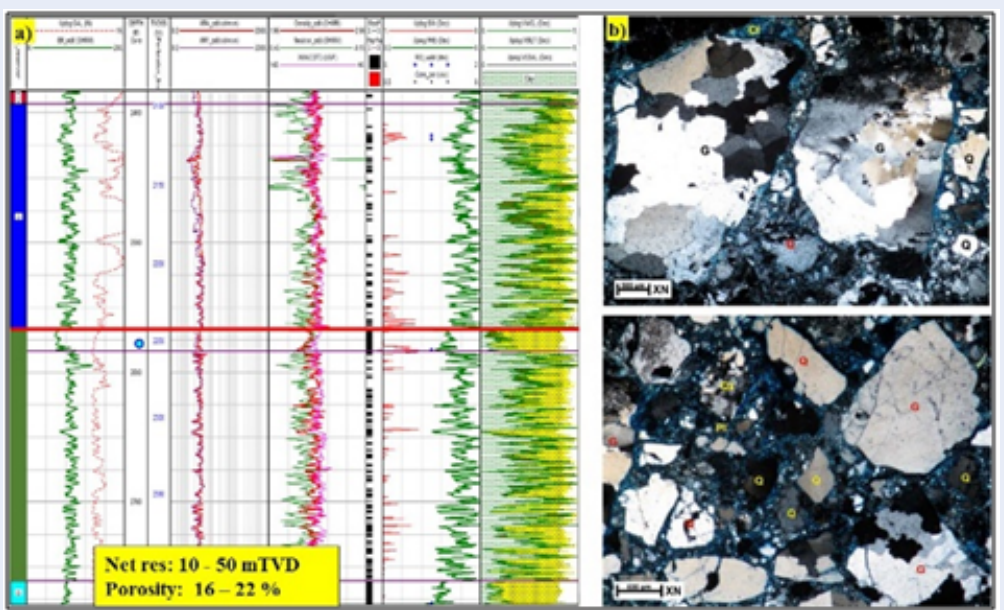

Figure 10: Reservoir characteristics of the fan trap in block 09-2/09 on Kn-2 well data: a) Petrophysical interpretation. In Kn wells, the trap reservoir is interpreted to have about $10 \mathrm{~m}$ to more than $50 \mathrm{~m}$ reservoir and porosity from $16 \%$ to more than $22 \%$; b) Petrographical analysis in reservoir interval showing mostly coarse-grained and poor sorted sandstones ${ }^{14}$.

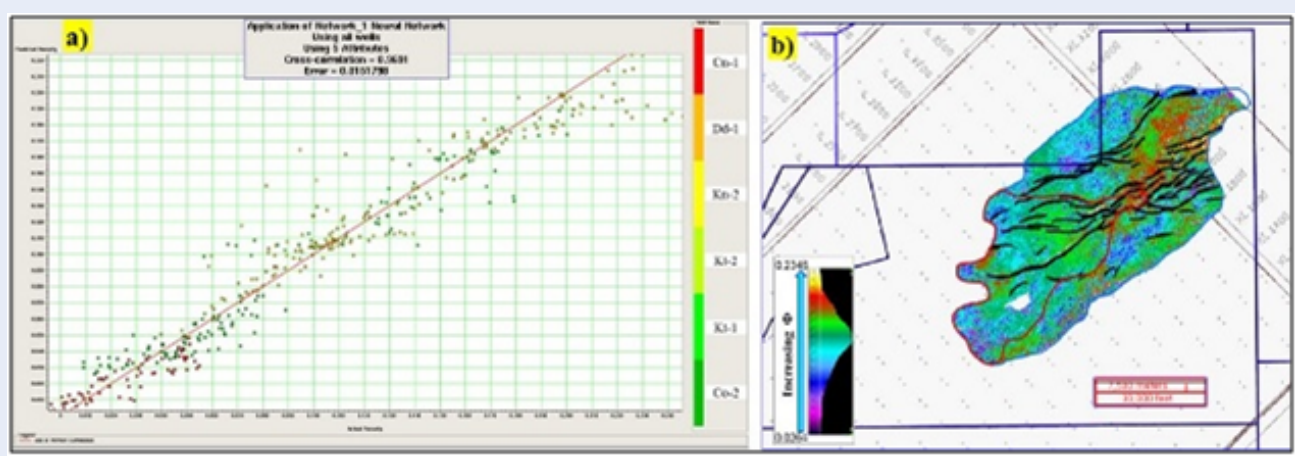

Figure 11: Prediction of reservoir porosity of stratigraphic fan trap in block 09-2/09. a) Correlation between the predicted porosities and the actual porosities; b) Predicted porosity map of the traps reservoir showing that the predicted porosities are from 12 to $20 \%$, consistent with those derived from well log interpretation. 


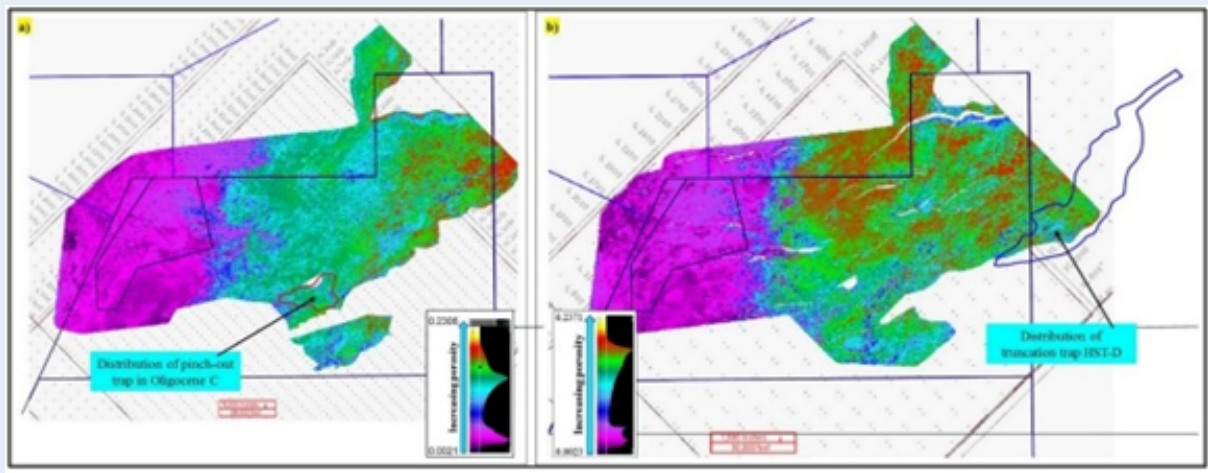

Figure 12: Reservoir porosity prediction for two stratigraphic traps in block 09-2/09. a) Predicted porosity map of pinch-out trap. In the traps area, the reservoir is predicted to have porosities from $9 \%$ to $16 \%$; b) Predicted porosity map of truncation trap. In the traps area, the reservoir is predicted to have porosities from $9 \%$ to $20 \%$.

The distribution of stratigraphic traps are evidenced in the eastern and southeastern areas of the basin. Some of them have been confirmed by drilling, thus making them important in oil and gas exploration.

- Structural traps were formed by postdepositional tectonic activities or draping over the existent topography highs with less risk in exploration, except for fault seal and migration in some places. The key forming factor for stratigraphic traps is lithology changes, tapering off of sand layers, or truncating of underlying strata. These stratigraphic traps have more risks in exploration than the structural ones; the risks are mostly sealing capacity of both top and bottom ones. Although the stratigraphic traps reservoir qualities are interpreted to be good, their distribution is one of the issues for prospecting these traps. Migration could also add more risks in exploring these traps in some places due to long distance to the source area.

- The existence of Oligocene stratigraphic traps and their hydrocarbon bearing reservoirs may confirm the importance of these traps and demand more attention to them in future exploration strategies and activities. However, further studies focusing on the petroleum system, especially top and bottom seals, and the hydrocarbon potential of these stratigraphic traps, need to be carried out in order to optimize the next-stage exploration strategy in CLB.

\section{COMPETING INTERESTS}

None of the authors reported any conflict interest related to this study.

\section{AUTHORS' CONTRIBUTIONS}

Dinh Chuc N: Coordinator of project

Van Xuan T: writing the papers draft, designing for research

Kha NX: collecting the data

Nhu Huy T: basic and geostatistic analysis

Tan MT: consultant of reseach design.

\section{ACKNOWLEDGMENTS}

The authors thank to PetroVietnam Exploration Production Corporation for the support and permission to publish this work. Contributing technical assistance and comments for this manuscript from Ho Chi Minh City University of Technology and PetroVietnam Domestic Exploration Production Operating Company Colleagues are greatly acknowledged and appreciated. This research is funded by Vietnam National University Ho Chi Minh City (VNU-HCM) under grant number C2018-20-33.

\section{REFERENCES}

1. Dong TL, Hai PD. Cuu Long basin and its petroleum resources. In: The Petroleum Geology and Resources of Vietnam. Vietnam: Ha Noi, The Science and Technology Publishing House; 2007. p. 264-309.

2. Cuong TM. Formation characteristics and distribution rule of non-structural traps in the north of Cuu Long basin; 2012. PhD thesis, Ha Noi University of Mining and Geology, Ha Noi.

3. VPI. Stratigraphic combination trap study," Joint study with PVEP POC, 2014, 93 pp; 2014.

4. Doi DQ. Evaluation of hydrocarbon potential resources in Cuu Long basin. VPl; 2012. p. 97-147.

5. PVEP-POC. "Updated Appraisal Plan for Kinh Ngu Trang Nam Discovery,"; 2014. Internal report to PVN and PVEP.

6. San NT, Truong VL, Hoang CM, Tri TV. "Vietnamese tectonics in southeast Asian structure frame,". In: The Petroleum Geology and Resources of Vietnam. Ha Noi, The Science and Technology Publishing House; 2007. p. 91-101. 
7. thi Luan B. Source rocks in Cuu Long basin. Science \& Technology Development. 2008;11(04):28-39.

8. Mitchum RM. P. R. Vail and and S. Thompson, "The depositional sequence as a basic unit for stratigraphic analysis,". Oklahoma: AAPG; 1977.

9. Myers K, Milton J. Concepts and principles of sequence stratigraphy. In: in Sequence Stratigraphy. London: Blackwell; 1996. p. 11-41.

10. Taner M. Seismic Attributes. CSEG Recorder. 2001;p. 48-55.

11. Chopra S, Marfurt K. Seismic Attributes - a promising aid for geologic prediction. CSEG RECORDED. 2006;p. 110-120.

12. Rider M. The Geological Interpretation of Well Logs, 2nd ed. In: Gulf Publishing Company. Gulf Publishing Company; 1996. p. 64-260.

13. Anh NL, Khuong NV, Anh NH. "Characteristics of Oligocene D stratigraphic traps in Ca Tam discovery, block 09-3/12, Cuu Long basin,.. In: Paleogene plays in Vietnam. Vung Tau; 2016. .

14. VPI. "Reports of petrographic and biostratigraphic analysis of wells in Kn,; 2014. Unpublished. 